\title{
Dengue and Dengue and Vector Behaviour in Cáqueza, Colombia, 2004
}

\author{
HERNÁN RODRÍGUEZ G. and FERNANDO DE LA HOZ R.
}

Received on 30 November 2004/Reviewed on 6 December 2004/Accepted 4 February 2005

\begin{abstract}
Objective Describing the behaviour of dengue and its vector in Cáqueza, Colombia (1 746 masl) by serological, entomological and virological monitoring between March and June 2004.

Methods Two types of study were carried out. One was a cross-sectional study for serologically monitoring the population and taking entomological indicators; participants were selected from the general population by random conglomerate sampling. The second study consisted of monitoring febrile cases suspected of dengue during a four-week period. Vector behaviour (bite-rate and hours of activity) was also included by using the landing-onhumans technique; a rubbish-collecting day was run during the same period for evaluating this intervention's short-term effectiveness.

Results Total prevalence of infection by dengue (IgG positive) was $23,3 \%$ in 252 people examined in the surveyed population. Household infestation index was 32,9 \%; deposit index was 8,4 \%; and Breteau index was 43,9. Following the rubbish-collection day, the infestation index became reduced by $56 \%$ (14,5\% post-intervention), deposit index by $43 \%$ (4,8 \% post-intervention) and Breteau index by $59 \%$ (17,9\% post-intervention). Two of the febrile patients $(n=83)$ were IgM positive.

Conclusions The study showed that dengue's urban vector can reach dangerous levels of infestation above 1700 masl; however, a deeper study of its bionomy is needed at these heights above sea-level during different times of the year for improving knowledge regarding climatic and environmental factors affecting their efficiency as vector in these conditions.
\end{abstract}

Key Words: Aedes aegypti, seroprevalence, sentinel surveillance, entomology,l indicators, Colombia (source: MeSH, NLM).

RESUMEN

Comportamiento del dengue y del vector en Cáqueza, Colombia, 2004 
Objetivo Describir el comportamiento del dengue y su vector en Cáqueza, Colombia, (1 $746 \mathrm{msnm}$ ), mediante vigilancia serológica, entomológica y virológica, entre Marzo y Junio de 2004.

Métodos Se realizaron dos tipos de estudio: Un estudio de corte transversal para la vigilancia serológica poblacional y el levantamiento de los indicadores entomológicos donde los participantes fueron seleccionados de la población general por muestreo aleatorio de conglomerados. El segundo estudio fue de vigilancia centinela sobre casos febriles sospechosos de dengue durante cuatro semanas, incluyendo el comportamiento del vector (tasa de picadura y horas de actividad) mediante la técnica de aterrizaje sobre el humano. Durante el mismo periodo se realizó una jornada de aseo lo que permitió evaluar la efectividad a corto plazo de esta intervención.

Resultados La prevalencia total de infección por dengue (IgG positivos) fue de $23,3 \%$ en 252 personas examinadas en la encuesta poblacional. El índice de infestación de viviendas fue de 32,9\%, el índice de depósito fue de $8,4 \%$ y el de Bretau de 43,9. Después de la jornada de aseo el índice de infestación se redujo en un 56 \% (14,5\% post intervención), el de depósito disminuyó en un $43 \%$ (4,8 \% post intervención) y el de Bretau en un $59 \%$ $(17,9$ post intervención). Entre los pacientes febriles $(n=83)$ dos fueron positivos para IgM.

Conclusiones El estudio sugiere que aunque hay presencia del vector, la transmisión interepidémica de dengue es baja en esta población. Con respecto al vector es importante porque hay pocos estudios del comportamiento del dengue en poblaciones por encima de 1500 metros en Latinoamérica.

Palabras Clave: Aedes aegypti, seroprevalencia, vigilancia, centinela, indicadores, entomológía, Colombia (fuente: DeCS, BIREME).

$\mathrm{I}$ has been calculated that 50 to 100 million cases of dengue and that (depending on the year) from 250,000 to 500,000 cases of hemorrhagic dengue occur each year around the world. Average yearly lethality rate is around $5 \%$ and most cases of death caused by dengue occur amongst children and young adults.

The incidence of classical dengue in Colombia since 1978 has fluctuated, having a tendency to increase, rising from 17,389 cases in 1997 to 81,831 in 2002. The same behaviour has been observed for hemorrhagic dengue (less than 5000 in 1998 to 5500 cases in 2002) (1). Behaviour for the Cundinamarca department has similarly increased, rising from 800 cases of classical dengue in 2000 to 2161 in 2003. There has also been an important occurrence of 150 and 300 cases of hemorrhagic dengue per year between 2001 and 2003 (2). 
Various dengue epidemics have occurred since 1970 following re-infestation by Aedes aegypti in Colombia, with the four serotypes circulating throughout the country. These four dengue serotypes are currently circulating throughout Colombia, though not having the same intensity. The dengue 2 virus was isolated in 1971 and has been circulating since then with dengue 1 . Dengue 4 began to circulate in 1984 and has continued to circulate since then to date. Dengue 3 circulated for a short period during the mid-1970s, disappearing for several years and reappearing in the Santander department in 2001 (1).

The main vector of dengue in Colombia is Aedes aegypti, its dissemination being limited by altitude. It has been found in Colombia at altitudes of up to 2200 metres above sea-level (masl), where annual temperature is $17^{\circ} \mathrm{C}$. This altitude is higher than the maximum internationally reported in India (2 121 masl). In spite of it being known that it can exist at these altitudes, its behaviour is not well-known above 1500 metres.

The current investigation was carried out to elucidate dengue epidemiological behaviour and that of its vector in Cáqueza (in the Cundinamarca department), lying at 1746 masl where the vector was found for the first time in 2003; however, no information regarding the virus' autochthonous circulation has been available to date. Data collected during this study could help in elucidating the behaviour of dengue and its vector at high altitude.

\section{MATERIALS AND METHODS}

Study site

Cáqueza is a town having a population of 21000 inhabitants, $63 \%$ of them living in the municipality's urban area. Its average temperature is $21^{\circ} \mathrm{C}$. It is situated near several municipalities, which have reported autochthonous dengue in the past.

Types of study

A cross-sectional study was carried out for serological monitoring of the population and taking entomological indicators. A serological sentry monitoring system was set up for determining the incidence of dengue in patients presenting the disease's acute symptoms. The short-term effectiveness of a rubbish-collecting day was also determined by recording entomological indexes following the intervention.

Sampling methods for the entomological and serological survey 
Multistage conglomerate sampling was done for determining seroprevalence and entomological indicators. 30 conglomerates were thus randomly selected from the urban area and 10 households were chosen from each townblock during a second stage. The urban map of Cáqueza had to be modified as the most up-to-date had been drawn up in 1998 and it was seen that the number of houses per block had increased. A cadastral engineer was enlisted to help in redesigning the cartographic plans. Once the changes had been made (and bearing the forgoing in mind), the map was then divided into sectors, then successively into barrios, blocks and houses. The percentage of houses per block was very unequal in some cases respecting other blocks; for example, one block had 10 houses whilst most had between 24-30 houses. The foregoing meant that blocks having such a low number of houses were grouped for levelling them out with the others. 35 conglomerates were finally left. 30 blocks and the households within each block were chosen to be studied by using a list of random numbers generated by Epitable software (EPIINFO 6.04). A total of 274 houses was visited, an average of 8 houses per block. 36 houses could not be surveyed because they were closed or because the inhabitants did not wish to be visited.

The most used variables in the serological survey were: block, age, gender, completed years of schooling, social security, travelling outside Cáqueza, using mosquito-netting, the main symptoms of dengue, previous diagnosis of dengue, sample-taking and Ig-G result.

Pre- and post-rubbish-collection day entomological monitoring Aedes indexes were constructed on two occasions. An initial one was taken for determining housing, deposit and Breteau percentages. Another index was taken later, helped by the mayor's office, following a rubbish-collection day. This was done after making the community aware of the need for collecting waste items, washing reservoirs, covering deposits, etc. The vector-born disease (VBD) helper and/or entomologist evaluated the different low deposits (reservoirs, drums, buckets or other recipients) and high deposits where the inhabitants kept their water (covered or uncovered water tanks), as well as diverse deposits where water collected, such as cans, tyres, jar/pots, bottles, plants, etc.

The following indicators were analysed:

Housing index (larval): positive houses / inspected houses x $100 \%$;

Deposit index: positive deposits / inspected deposits x $100 \%$; and

Breteau index: positive deposits / inspected houses x 100 houses inspected. 
Sentry serological monitoring in patients having a clinical picture compatible with dengue

This was done for 4 weeks between June and July by processing 24 patients' samples per week. Sample screening was calculated with $95 \%$ reliability for detecting $30 \%$ prevalence, assuming that at least 3 were positive (3). The reference population consisted of people residing in Cáqueza's urban area consulting San Rafael hospital's outpatient services (sentry centre) for symptoms compatible with dengue and who had been living in dengue endemic areas during the 10 days prior to consultation.

Defining a febrile case

This would have been a patient who had consulted as he/she had presented temperature greater than or equal to $38^{\circ} \mathrm{C}$, having at least 5 days' evolution and having lived for more than 10 days in the area, plus the following signs and symptoms:

General: chills, photophobia, prostration, discomfort and diaphoresis;

Osteo-muscular: arthralgia and myalgia;

Gastrointestinal: nausea, vomiting, anorexia, diarrhoea and abdominal pain; and

Hemorrhagic: haematemesis, epistaxis, ecchymosis, haemoptysis, melena.

Samples were taken for IgM if the above conditions were complied with.

Inclusion criteria

The following criteria were taken into account:

- $\quad$ Patients being aged more than 5, fulfilling case criteria;

- $\quad$ Presenting probable signs and symptoms of dengue; and

- Wishing to participate in sentry monitoring.

Exclusion criteria

The following criteria were taken into account:

- $\quad$ Oral temperature less than $38^{\circ} \mathrm{C}$;

- Having a febrile picture with more than 3 weeks' evolution;

- $\quad$ Being aged less than 5;

- Visible causes of another infectious disease (tonsillitis, acute respiratory infection, media otitis, etc); and

- $\quad$ The lack of authorisation by the patient or person consulting hospital services for a blood-sample to be taken. 
Landing-on-humans technique

The vector's bionomy was also studied, bearing in mind its behaviour, hours of peak-activity, bite rate, etc. Conditions for collecting, sending and transporting samples to the Cundinamarca Public Health Laboratory strictly adhered to the protocol established by the Laboratory's Entomology Unit. The format for remitting samples was similarly filled in specifying the date of capture, place, gender, collector's name and identification on the collectingflask coinciding with the date of having been sent to the laboratory.

Adult mosquitoes which had been collected were killed with cold / cigarette smoke and then carefully packed in plastic boxes to be sent to the public health laboratory to be read by the entomologist (careful packing was stressed for ensuring that basic structures were not lost for later taxonomic identification).

6 visits were made to the town accompanied by a VBD assistant having experience in this activity. 4 nights were spent in the following sites from 6 pm to 6 am: Hospital San Rafael de Cáqueza, the Departmental gardens and two private houses.

Time was spent in the two following places during the day from 8 am to 6 pm: Hospital San Rafael de Cáqueza and the Departmental gardens.

Sample-taking

Random serum sampling (only 1 inhabitant per household) was done for the seroprevalence survey (anti-dengue IgG) for a total of 253 samples. Those people were identified who had had symptoms compatible with dengue during the last year. A serum sample was taken on day 6 and then on from cases having had an acute febrile clinical picture (sentry monitoring) during the last 10 days for processing them for anti-dengue IgM (giving a total of 83 patients). Written informed consent was always asked and given for both types of monitoring when collecting and processing samples.

The following recommendations were taken into account (7):

$10 \mathrm{ml}$ blood was obtained and placed in a sterile tube without anticoagulant; Samples were then left to coagulate at room temperature for a period of at least 30 minutes and not more than 2 hours until coagulum became completely retracted; 
Samples were then centrifuged at $3000 \mathrm{rpm}$ for 20 minutes; and Serum samples were finally put into duly labelled (name and date sample was taken) sterile screw-topped tubes in aseptic conditions.

Sample conservation and transport

Samples were sent as soon as possible in refrigerated conditions to the Cundinamarca Public Health Laboratory where they were processed by the bacteriologist responsible for this area, using Tecnosuma kits. Each batch of samples was accompanied by its respective laboratory order.

\section{RESULTS}

Data was collected using instruments designed for such purpose. Survey population data, such as that for the sentry population, was loaded using EpiInfo software (version 3.2.2) and then exported to SPSS (version 12) for respective analysis.

Serologically monitoring the population $75,6 \%$ (95 \% CI=70,3; 80,7) of the total of 253 people surveyed were female. Ages ranged from 6 to 85 ( $\mu=39,6$ years old, $95 \% \mathrm{CI}=37,4 ; 41,8$ ). 38 $\%$ of the people were affiliated to the subsidised health insurance regime $(\mathrm{n}=101), 37,8 \%$ were affiliated to their contributory regime $(\mathrm{n}=99)$ and $23 \%$ $(n=60)$ were not affiliated to the Colombian General Social Security in Health System.

The average of years spent living in the town was 27,4 (95\% CI=24,9; 29,9), ranging from 1 to 82 years. $66 \%$ of the people had been outside the town during the last year $(\mathrm{n}=173)$. Only $7.9 \%$ of the population surveyed used a mosquito-net when sleeping $(\mathrm{n}=20)$.

There was 23,3 \% (95 \% CI=18; 28) ( $=59$ ) prevalence of infection caused by dengue (IgG positive), whilst $28,8 \%$ of those positive for Ig-G had had symptoms of dengue during the last year (95 \% CI=17,9; 42,8).

It was found that the $\mathrm{p}$ value was not statistically significant for either bivariable or multivariable analysis when measuring association between being infected by dengue and some independent variables such as travelling or not having been outside Cáqueza, using or not using a mosquito-net, having or not having had symptoms of dengue and prevalence of dengue per block. The exception was the last independent variable (OR: 1.06; 95\% $\mathrm{CI}=1.04 ; 1.07 ; \mathrm{p}<0.001$ ), i.e. having other people infected on a town block was significantly related to the probability of being infected by dengue. 
Pre-rubbish-collection-day entomological monitoring

Total larval index per block was 32,9 \% (95 \% CI=31,02; 35,0), ranging from $0 \%$ to $66,6 \%$, $30 \%$ mean. Total deposit index was 8,3\% (95 \% CI=9,0; $10,4)$, ranging from $0 \%$ to $24,2 \%, 8,6 \%$ mean. Total Breteau index was 43,2 (95 CI=40,2; 46,2), ranging from 0 to 100, 42,8 mean.

Table 1 shows how positive a breeding place was according to type of breeding place. Being positive was higher in lower tanks (28\%) pre-rubbishcollecting day than the most numerous breeding place following it. An important reduction could be observed in being positive in lower tanks postrubbish-collecting day whilst no reduction took place in other types of breeding place; on the contrary, being positive increased in some cases.

Table 1. Positivity of Aedes aegypti breeding places Pre- and post-rubbish-collection day. Cáqueza, Cundinamarca, 2004

\begin{tabular}{|c|c|c|c|c|c|c|}
\hline \multirow[b]{2}{*}{$\begin{array}{c}\text { Type breeding } \\
\text { place }\end{array}$} & \multicolumn{2}{|c|}{ Observed } & \multicolumn{2}{|c|}{ Infested } & \multicolumn{2}{|c|}{ \% positive } \\
\hline & $\begin{array}{l}\text { Pre-rubbish- } \\
\text { collecting day }\end{array}$ & $\begin{array}{l}\text { Postrubbish- } \\
\text { collecting } \\
\text { day }\end{array}$ & $\begin{array}{c}\text { Prerubbish- } \\
\text { collecting } \\
\text { day }\end{array}$ & $\begin{array}{l}\text { Postrubbish- } \\
\text { collecting } \\
\text { day }\end{array}$ & $\begin{array}{l}\text { Prerubbish- } \\
\text { collecting } \\
\text { day } \%\end{array}$ & $\begin{array}{l}\text { Postrubbish- } \\
\text { collecting } \\
\text { day }\end{array}$ \\
\hline High tanks & 164 & 251 & 3 & 0 & 1,8 & 0,0 \\
\hline Low tanks & 301 & 348 & 84 & 32 & 27,9 & 9,1 \\
\hline Tyres & 38 & 32 & 1 & 5 & 2,6 & 15,7 \\
\hline Plants & 278 & 45 & 6 & 3 & 2,1 & 6,7 \\
\hline Different places* & 646 & 428 & 24 & 9 & 3,7 & 2,1 \\
\hline Total & 1427 & 1104 & 118 & 49 & 8,2 & 4,4 \\
\hline
\end{tabular}

Post rubbish-collection-day entomological monitoring

Total larval index was $14,5 \%(95 \% \mathrm{CI}=10,8 ; 19,1)$, ranging from $0 \%$ to $44,4 \%, 11,1 \%$ mean. There was $56 \%$ reduction respecting pre-rubbish-collecting day indexes.

Total deposit index was 4,8 \% (95\% CI=3,5; 6,2) ranging from $0 \%$ to 28 $\%, 4,6 \%$ mean. There was a $43 \%$ reduction following the rubbish-collecting day. Total Breteau index was 16,7 (95\% $\mathrm{CI}=12.8 ; 21.6)$, ranging from 0 to $63,6,12,5$ mean. There was $59 \%$ reduction respecting pre-rubbish-collecting day indexes. 
Table 2 shows distribution by gender and specie of larvae captured between February 2004 and August 2005. It can be seen that Aedes aegypti was the most frequently identified gender, followed by Culex quinquefasciatus. Least captures were made during June.

Table 2. Specie and genus of larvae captured per month. Cáqueza, Cundinamarca,

\begin{tabular}{lccccccc}
\hline Month & $\begin{array}{c}\text { Aedes } \\
\text { aegypti }\end{array}$ & $\begin{array}{c}\text { Aedes } \\
\text { fluviatilis }\end{array}$ & $\begin{array}{c}\text { Culex } \\
\text { quinquefasciatus }\end{array}$ & $\begin{array}{c}\text { Culex } \\
\text { coronator }\end{array}$ & $\begin{array}{c}\text { Culex } \\
s p\end{array}$ & $\begin{array}{c}\text { Linatus } \\
\text { durhami }\end{array}$ & $\begin{array}{c}\text { Anopheles } \\
\text { argyritarsis }\end{array}$ \\
\hline February & 10 & 0 & 0 & 0 & 0 & 0 & 0 \\
April & 509 & 1 & 13 & 1 & 29 & 1 & 0 \\
May & 142 & 0 & 37 & 1 & 0 & 0 & 8 \\
June & 0 & 1 & 8 & 41 & 3 & 0 & 0 \\
August & 114 & 10 & 8 & 0 & 1 & 0 & 0 \\
\hline Total & 775 & 12 & 66 & 43 & 33 & 1 & 8 \\
\hline$\%$ & 83 & 1,2 & 7 & 4,6 & 3,5 & 0,1 & 0,8 \\
\hline
\end{tabular}

Rate of landing-on-humans

Table 3 shows the places, times, date and type of capture of adult male and female Aedes aegypti and Culex Sp. Aedes aegypti never circulated at night; captures coincided with daylight hours and dusk, as one would expect with this vector. $62 \%$ to $90 \%$ relative humidity was observed during daylight captures and temperature ranged from $21{ }^{\circ} \mathrm{C}$ to $34^{\circ} \mathrm{C}$. There was $82 \%$ to 100 $\%$ humidity during the nights, this value coinciding with hours of rainfall and temperature ranging from $17^{\circ} \mathrm{C}$ to $26^{\circ} \mathrm{C}$.

Adults captured by using the landing-on-humans method (both intra- and peri-domicilium were Culex sp; Aedes aegypti were only captured at rest. The bite-per-hour rate was 4 adults per hour for Culex, being registered in the peridomicilium from 18:00-19:00 and 21:00-22:00.

Sentry monitoring of febrile cases

83 cases of fever compatible with dengue were studied. $59 \%$ of them were women; minimum age was 5 years, maximum being 85 , average 29,7 years old (95\% CI=26,3-33).

$34,9 \%$ of patients had been beyond Cáqueza during the last 10 days $(\mathrm{n}=29)$. Endemic-epidemic sites for dengue which they had been to were: Villavicencio, Restrepo, Cartagena, Carmen de Apicalá, Guayabetal, Melgar, Ibagué, Girardot and Vichada. The most representative site was Villavicencio which 12 residents had been to as tourists and for business. 
The main signs and symptoms reported by patients in the sentry monitoring process were fever $(100 \%)$, headache $(95,1 \%)$, bodily pain $(87,9 \%)$ and exanthema $(83,1 \%)$.

Two patients proved positive for IgM (2,4 \%). The first (aged 42), had not been beyond Cáqueza during the 10 days before onset of symptomatology. Ig-M had been taken 8 days after the onset of symptoms. The other case (aged 33) had also not been outside the town during the previous 10 days. The sample had been taken 5 days after onset of symptoms. Both cases stated that they had visited Villavicencio three months previously; however, they only referred to having had recent symptoms of dengue leading to them consulting sentry monitoring.

\section{DISCUSSION}

Studies carried out in Colombia during the last 25 years have corroborated finding the vector above 1600 masl, as has happened in Fusagasugá (Cundinamarca) lying at 1728 masl and Málaga (Santander) at 2200 masl (4). This means that the presence of the Aedes aegypti vector in the municipality of Cáqueza (1 741 masl) shows that this mosquito has been becoming adapted to altitudes greater than 1500 masl during recent years. Public and private means of transportation, accelerated processes of urbanisation and man's intervention are amongst the main causes of the vector's propagation and distribution (5).

The level of dengue's seroprevalence (23,3\%) and the vector's high infestation rate suggest that dengue has been transmitted in Cáqueza; this, added to the fact of being a town attracting the tourist trade, makes the risk of inter-epidemic transmission become high. Seroprevalence levels found in Caqueza were lower then those found in Girardot (289 masl), i.e. 89 \% (6). On the other hand, they were slightly higher than those found in Medellín (1 538 masl), i.e. $16,3 \%$ (7). Seroprevalence has been found to be $33 \%$ in Colima, México (490 masl) (8).

The high percentage of inhabitants engaging in unsuitable practices for controlling dengue must be stressed. Inhabitants in $75 \%$ of households were used to hoarding a lot of waste items (cans, bottles, jar/pots, tyres), to not cleaning low deposits suitably and leaving them open (uncovered), thus making both aspects into the main risk factors for Aedes aegypti proliferation. Reservoirs and tyres represent the best larval habitat, whilst bedrooms are adult mosquitoes' preferred habitat (9). 
Other sectors of the municipality such as municipal educational centres, the hospital and cemetery aid the vector's growth and proliferation due to the presence of elements (flower vases, jar/pots, tyres) containing stagnant water for long periods of time. Areas in Rio de Janeiro, Brazil, have remained positive for Aedes aegypti such as scholastic concentrations and other places due to their immediate environmental conditions being predisposed towards oviposture (10).

Another important aspect in the spread of the vector's presence to surrounding rural areas is due to their closeness to the urban area allowing Aedes aegypti to travel to these neighbouring territories. This vector's dispersion by flight is very limited when compared to other mosquito species. 100-metre flight dispersion is considered rare, but it has been shown that a pregnant female can fly up to $3 \mathrm{~km}$ to deposit her eggs (11).

One of the study's strengths was that $83 \%$ of samples collected during the five months spent collecting larvae corresponded to Aedes aegypti; this fact shows the VBD assistants level of training which contributed towards constructing the indexes.

One of this study's important limitations was revealed by scant adult Aedes aegypti captures by the landing-on-humans method for determining their behaviour and bionomy. Captures were also made at rest, contrasting with collecting adult Culex sp, which was much greater, using the same technique. Capturing mosquitoes when they alight on humans and bite them represents a sensitive means of detecting low-level infestations, but requires a lot of personnel. Both male and female Aedes aegypti mosquitoes are attracted to human-beings and, bearing in mind that males present low dispersion indexes, their presence could thus be a trustworthy indicator of the proximity of hidden breeding-places.

The rubbish-collection day and mass awareness-raising campaign, together with training and prevention activities run with the community, an important reduction was shown in most households' infestation indexes, even more so when these activities were concentrated in higher risk deposits. The 3 entomological indexes ostensibly became reduced by between $43 \%$ and 59 $\%$; low deposits' positivity percentages importantly diminished post-rubbishcollecting day.

As sentry monitoring for IgM (finding low sero-reactivity) was only carried out for four weeks, this represented another limitation. This leads to it being thought that this type of monitoring should be done periodically (four- 
monthly) together with virological monitoring (which could not be carried out in this study) to be alert to the imminence of an outbreak of dengue. Even though the latter type of monitoring is essential, it has been demonstrated that viral isolation is minimal when epidemics happen (12). This study has shown that dengue's urban vector can reach dangerous infestation levels in places lying above 1700 masl. However, its bionomy must be studied more deeply at these altitudes during different times of the year for improving knowledge regarding climatic and environmental factors affecting its efficiency as a vector in such conditions

Acknowledgements. We would like to thank A Victor Olano from the Instituto Nacional de Salud, the people working in the Cundinamarca Public Health Laboratory (especially Pilar Carrillo and Félix Ruiz), the Tecnosuma Laboratory (especially León Dovale Durán and Patricia Muñoz), health workers in Hospital San Rafael de Cáqueza, the Mayor's office in Cáqueza, VBD assistants, William León and everyone else who has helped in carrying out this study. 
Table 3. Type of capture of adults according to time and place Cáqueza, Cundinamarca, 2004

\begin{tabular}{|c|c|c|c|c|c|c|c|c|}
\hline \multirow{2}{*}{$\begin{array}{l}\text { Date of } \\
\text { capture }\end{array}$} & \multirow{2}{*}{ Time } & \multirow{2}{*}{ Place } & \multirow{2}{*}{ Site } & \multirow{2}{*}{ Type of capture } & \multicolumn{2}{|c|}{ Aedes aegypti } & \multicolumn{2}{|c|}{ Culex sp } \\
\hline & & & & & Female & Male & Male & Female \\
\hline 06/04/04 & $20-21$ & Private household & Study & Intra- domicilium human bait & & & 1 & 1 \\
\hline $06 / 04 / 04$ & $21-22$ & Private household & Study & Intra- domicilium human bait & & & 3 & 3 \\
\hline $06 / 04 / 04$ & $4-5$ & Private household & Bedroom & At rest & & & 4 & \\
\hline 07/04/04 & $5-6$ & Private household & Bedroom & At rest & & & & 3 \\
\hline $14 / 04 / 04$ & $18-19$ & Departmental gardens & Bathroom & At rest & & & 1 & 2 \\
\hline $21 / 04 / 04$ & $21-22$ & Departmental gardens & Living room & Intra- domicilium human bait & & & 1 & 1 \\
\hline $21 / 04 / 04$ & $22-23$ & Departmental garden & Bathroom & At rest & & & 2 & 2 \\
\hline $22 / 04 / 04$ & $1-2$ & Departmental garden & Living room & Intra- domicilium human bait & & & & 2 \\
\hline $22 / 04 / 04$ & $4-5$ & Departmental garden & Bathroom & At rest & & & 3 & \\
\hline $22 / 04 / 04$ & $6-7$ & Departmental gardens & Bathroom & At rest & & & 1 & \\
\hline $04 / 05 / 04$ & $12-13$ & Hospital & Car-park & Intra- domicilium human bait & 1 & 1 & & \\
\hline $11 / 05 / 04$ & $18-19$ & Hospital & Outpatient & Intra- domicilium human bait & & 1 & & 1 \\
\hline $11 / 05 / 04$ & $21-22$ & Hospital & Outpatient & Intra- domicilium human bait & & & & 1 \\
\hline $11 / 05 / 04$ & $23-24$ & Hospital & Car-park & Intra- domicilium human bait & & & & 1 \\
\hline $\begin{array}{l}12 / 05 / 04 \\
20 / 05 / 04\end{array}$ & $\begin{array}{r}4-5 \\
12-13\end{array}$ & $\begin{array}{c}\text { Hospital } \\
\text { Colegio Santiago } \\
\text { Gutiérrez }\end{array}$ & $\begin{array}{l}\text { Outpatient } \\
\text { Bathroom }\end{array}$ & $\begin{array}{l}\text { Intra- domicilium human bait } \\
\text { At rest }\end{array}$ & 2 & 3 & & 1 \\
\hline 20/05/04 & $14-15$ & $\begin{array}{l}\text { Colegio Santiago } \\
\text { Gutiérrez }\end{array}$ & Bathroom & At rest & 4 & 1 & & 2 \\
\hline 08/06/04 & $19-20$ & House particular & Corridor & Intra- domicilium human bait & & & & 2 \\
\hline \multirow[t]{2}{*}{ 08/06/04 } & $20-21$ & House particular & Corridor & Intra- domicilium human bait & & & 1 & \\
\hline & & & & Total & 7 & 6 & 17 & 22 \\
\hline
\end{tabular}




\section{REFERENCES}

1. Mera C, García I, Velandia M, Bernal M, Cedeño D, Serna MT et al. Sistema de vigilancia sindrómica sobre enfermedades febriles transmitidas por vectores, con énfasis en fiebre amarilla, dengue y malaria en los departamentos de Guaviare, Putumayo, Caquetá y Norte de Santander, 2002. Inf Qinc Epidem Nac 2003; 8(5):74-83.

2. Sánchez JF. Las jornadas departamentales, una estrategia fundamental para la prevención y control del dengue. Boletín Epidemiológico de Cundinamarca 2002; 3 (1):55-65.

3. Lwanga S, Lemeshow S. Determinación del tamaño de las muestras en los estudios sanitarios. WHO.1991. p.65.

4. Suarez MF, Nelson MJ. Registro de altitud del Aedes aegypti en Colombia. Biomédica 1981; 1(4):225.

5. Tauil P. Urbanization and dengue ecology. Cad. Saúde Pública, 2001;17: 99-102.

6. Gaviria AM. Estudio seroepidemiológico y de conocimientos, actitudes y prácticas sobre control y prevención del dengue. Colegio Mayor de Antioquia, 1998. Informe Quincenal Epidemiológica Nacional, 1999; 4(15):226-229.

7. Farieta S. Estudio de identificación de áreas críticas del dengue en función del riesgo epidemiológica en el municipalidad de Girardot. Madrid: Facultad de Ciencias. Universidad de Barcelona; 2002.

8. Espinoza F, Hernández C, Rendón R. Transmisión ínterepidémica del dengue en la ciudad de Colima, México. Salud Pública de México, 2003; 45(.5):365-370.

9. Tinker M, Olano V. Ecología del Aedes aegypti en un pueblo de Colombia, Sur América. Biomédica 1993; 13(1):5-14.

10. Reinaldo Souza R, Sá Carvalho M. Spatial analysis of Aedes aegypti larval distribution in the Ilha do Governador neighborhood of Rio de Janeiro, Brazil. Cad. Saúde Pública, 2000; 16(1):31-42.

11. Dengue y dengue hemorrágico en las Américas: Guías para su prevención y control. OPS; 1995. Publicación Científica No 548: p.3-34.

12. Camacho T, De la Hoz F, Cárdenas V, Sánchez C, De Calderón L, Pérez L, et al. Vigilancia epidemiológica incompleta de la epidemia de Dengue-2, en Ibagué, Colombia. Biomédica, 2004; 24(2):174-182.

13. Lloyd L. Mejores prácticas para la prevención y el control del dengue en las Américas. USAID; February 2003.

14. Acha P, Ciprés B. Zoonosis y enfermedades transmisibles comunes al hombre y a los animales. OPS; 1997. Publicación Científica Nº 503; p.302-305.

15. Guzmán M, Kouri G. Dengue: an update. The Lancet, 2002; 2:33-42.

16. Biología y control del Aedes aegypti. Center for Disease Control. Vector topics. 1980; 4: 1-80.

17. Benenson A. Manual de control de las enfermedades transmisibles en el hombre. Décimo quinta edición. OPS. Publicación científica No 538; 1992. p.82-88.

18. Suarez M. Aedes aIbopictus (Skuse) (Diptera, culicidae) en Buenaventura Colombia. Inf Qinc Epidem Nac 2001; 6(15):222-223.

19. Cuzzubo A, Vaughn D, Nisalak A, Solomon T, Kalayanarooj S, Aaskov J, et al. Comparison of panbio dengue duo IgM and IgG capture ELISA and venture 
technologies dengue Ig $\mathrm{M}$ and IgG dor blot. Journal of clinical virology 2000; 16:135-144.

20. Mancheno M, Kroeger A, Alvarez G. Manual técnico para el control de malaria, dengue, leishmaniosis y oncocercosis. Editorial Servi offset; 2000. p.81-98.

21. Giraldo GP, Cuevas H, Pabón JD, Padilla JC. Comportamiento del dengue clásico asociado con la temperatura superficial del mar como indicador del ciclo ENOS en Colombia, 1980-1998. Informe Quincenal Epidemiológica Nacional, 1999; 4(21):322-327). 
